\title{
DINAMIKA KAJIAN EKOLOGI INTEGRATIF, DALAM MEMBANGUN POLA PEMBANGUNAN YANG BERKELANJUTAN
}

\author{
KRISTIYANTO \\ Kristiyanto94@gmail.com \\ NETTY DEMAK H. S \\ Program Studi Pendidikan Biologi, Fakultas Teknik, Matematika \& IPA \\ Universitas Indraprasta PGRI
}

\begin{abstract}
Abstrak
Pola-pola pembangunan saat ini, mencerminkan bagaimana masyarakat dalam menyikapi kekayaan maupun potensi ekologi-lingkungan sekitar, untuk modal dalam pembangunan, di samping perannya sebagai pengemudi dan pengontrol ritme alam, sehingga menentukan stabilitas dinamika hubungan antara sesama dan alam sekitar. Di samping itu, keseimbangan tatanan alam, juga dapat dibangun dan tercipta dari perkembangan ilmu pengetahuan serta teknologi (IPTEKS),yang dikembangkan untuk memudahkan manusia mengeksplore lebih jauh kekayaan atau potensi tatanan ekologi-lingkungan dengan segala konsekuensinya. Oleh karena itu, dimensi kajian ekologi mempunyai peran penting dalam mendeteksi, merefleksi dan mengevaluasi dinamika pembangunan tersebut, sertamampu menentukan langkah kedepan, yang mengarah pada keseimbangan alam yang komprehensif dan integratif, baik secara ekologis maupun non ekologis. Kajian pustaka (Library Research)dan pengamatan intensif (Depth-Observations), yang digunakanuntukmenganalisa kontens dari fenomena ekologismaupun non ekologis, sehingga elaborasi maupunkolaborasikeilmuan sangat dibutuhkandalammemahamidinamikatatananekologismaupun non ekologis, terkaitadanyaproses pembangunan yang terusberjalan. Asumsi mengenai hubungan manusia dengan alam tidak akan tercapai keseimbangan atau harmonisasi, bilamana paradigma pembangunan yang dibangunnya tidak mencerminkan atau merepresentasikan pada kaidah-kaidahekologis yang berlaku. Oleh karena itu, kerusakan demi kerusakan ekologis terus mengalami peningkatan dengan tahap yang semakin mengkwatirkan, yang tentunya dapat mengarah pada tahap kerusakan non ekologis (konflik sosial, ekonomi, budaya, politik, bahkan agama), bilamana tiadanya solusi yang strategis dan alternatif, dalam meresponnyasecaraadaptifdanpersuasif.
\end{abstract}

Kata Kunci: PotensiEkologi-lingkungan,KeseimbanganEkologisdan Non ekologis, KaidahEkologis, sertaPembangunan Berkelanjutan

\section{PENDAHULUAN}

Kompleksitas kajian ekologi terus mengalami perubahan dan perkembangan yang pesat (Samuel M. Scheiner et al, 1993; Alan R. Johnson, 1994; James D. Proctor, 2005), seiring dengan adanya fenomena ekologis maupun non ekologis, ditengah-tengah kehidupan masyarakat yang terus dihadapkan dengan masalah pembangunan yang semakin tidak ramah lingkungan. Melihat bagaimana menggeliatnya dinamika perubahan dan perkembangan paradigma pembangunan kini, dengan pola-pola pembangunan yang semakin modern, seakan telah mencapai tahap kehilangan arah yang tidak sesuai dengan visi dan misi pembangunan, yang sesungguhnya. Setiap ada pembangunan, memiliki 
konsekuensi atau dampak, yang merugikan baik secara ekologis maupun non non ekologis didalamnya. Itulah diantara salah satu permasalahan yang perlu adanya solusiyang kreatif, aktif, dan konstruktif,sesuai dengan kondisi dan situasi yang ada, sehingga tidak hanya pada tataran konsep, tetapi juga pada tataran aplikatif, sehingga perlu adanya proses elaborasi atau perpaduan kajian ekologi, yang solid dan berkelanjutan (David C Coleman, 2011), walaupun dipihak lain pemahaman kajiannya masih dihadapkan dengan pemaknaan yang bias, yang menurut Karen E. Hodges (2008), masih perlu adanya spesialisasi, agar terhindar dari kesamaan makna secara leksikal.

Di samping itu, sains dengan paradigma dan konsep yang dibawanya telah membawa perubahan yang masif dan komprehensif (Kaeksi, 1996), yang tentunya pada awalnya bagian dari khasanah keilmuan untuk mengeksplore sumber daya alam yang konstruktif dalam membangun peradaban manusia yang lebih bermartabat dan bermanfaat bagi kehidupan manusia yang lebih layak (Baqir et. all, 2005). Adapun dipihak lain dimensi agama, seakan ditanggalkan untuk mencapai puncaknya, didalam dinamika kehidupan manusia dalam berinteraksi dengan alam, padahal agama menganjurkan untuk terus mengamati perkembangan zaman dengan seksama, untuk kemajuan kini dan kedepan. Semua berjalan tanpa adanya sebuah permasalahan yang muncul dan masyarakat terus mengalami kemajuan dalam berbagai bidang keilmuan, yang kemudian muncul sebuah penciptaan teknologi yang kini semakin modern dan canggih dalam berbagai dimensinya, baik dari fungsi dan dampaknya.

Kemajuan dengan perkembangan sains dan teknologi, menciptakan sebuah khasanah keilmuan baru pada pandangan manusia terhadap alam sekitar, sehingga dengan kamajuan tersebut, manusia mengganggap paling berkuasa atas semua (Fromm, 2011). Bahkan manusia mengklaim, bahwa sains adalah segala-segalanya dan dengan sains mampu memecahkan segala permasalahan yang ada. Kemajuan tersebut, secara umumnya diakui bersama merupakan tuntutan dan tantangan untuk terus diusahakan dengan semaksimal mungkin, bahkan semua agamapun mengharuskan umatnya untuk terus tumbuh dan berkembang didalam kehidupannya, yang tentunya mempunyai dampak positif dalam proses kehidupannya yang sesuai dengan arahan dan pedoman dalam kitab sucinya masing-masing.

Oleh karena itu, hubungan manusia dan alam (Hadi, 2010; Soemarwoto, 1994), secara tidak langsung mengalami sebuah dilema didalam interaksinya, sehingga perlu adanya re-interpretasi agar tercipta sebuah keseimbangan. Secara historis, ketidakstabilan hubungan tersebut, terpacu sebagai akibat dari dampak akumulasiimplementatifparadigma revolusi industri yang selalu mengalami perubahan dan perkembangansecaradinamis. Paradigma tersebut, kini telah merambah diberbagai wilayah, secaralokal, regional, bahkanglobal, dengan membawa perubahan diberbagai aspek lini kehidupan manusia. Kemudahan akan akses, dan bahkan melintas batas geografis bagian dari perkembangan sains dan teknologi yang kini, menjadi tumpuhan besar dalam mengelola dan memanfaatkan sumber daya alam yang ada didalam maupun permukaan bumi. Hal tersebut, tentunya menjadi kesuksesan tersendiri, sehingga tidak mengherankan akan kemajuan yang kini dinikmati dan dirasakan.

Segala sesuatu yang telah diraih manusia, tentunya menjadi sebuah refleksi ulang atau re-evaluasi dalam menjalankan sebuah hubungan yang dinamis dan tentunya mengarah pada keberlanjutan atau eksistensi antara manusia dan alam. Apakah fenomena tersebut, sudah mengarah pada tujuan itu? Inilah yang perlu digali dan dibedah akan hubungan manusia dan alam yang mempunyai siklus yang mulai berseberangan atau bertentangan. Apapun yang kini, telah diraih atau dicapai sebuah peradaban modern, tentunya diharapkan tidak mengurangi sensitifitas rasa sebagai manusia yang juga bagian dari alam dalam berhubungan dan berinteraksi. 
Keberhasilan manusia didalam memahami fenomena alam denganbaikdanekologis, sepatutnya menjadi bagian dari peningkatanrasa sensitifitas, bahkankesadaran manusia yang mengarahpada instingatau rasa sensitifekologismaupun non ekologis (Panov V. I, 2013). Sebagaimana yang diketahui, bahwa manusia mempunyai keunggulan dalam panca indera dibanding dengan jenis makhluk hidup lainnya, tetapi dinamika paradigma pembangunan yang terus berubah dan berkembang, telah membelenggu keunggulan tersebut (Baca alinea berikutnya). Potensi manusia sebagai Khalifah, seakan sudah kehilangan arah akan rasa tanggung jawabnya untuk selalu menjaga dan memelihara lingkungan secara berkelanjutan.

Di samping itu, dimensi manusia (Abidin, 2003), sedikit diuraikan dalam ilmu filsafat, memang sangat sulit diuraikan secara detail dan kompleks, karena sifatnya yang dinamis, disamping banyak dipengaruhi kondisi dan situasi lingkungan sekitar, baik secara lokal, regional, maupun global, yang tentunya ini menjadi kajian menarik untuk memahami perubahan lingkungan dikaji dari aspek prilaku manusia sebagai agen utama dalam dinamika perubahan tersebut. Untuk itulah aspek manusia dilihat dari ilmu ekopsikologi sangat penting dalam mendukung dalam mengukur hubungannya secara detail. Keterkaitan tersebut, sangat ditentukan dari dampak prilaku manusia dalam arti dari dimensisosial, ekonomi, dan budaya yang tercipta, yang tentunya akan mempengaruhi persepsi dan interpretasi manusia terhadap tatananalam sekitar.

Kajian-kajian tentang dimensi manusia, terkait aspek eko-psikologi, sudah banyak dilakukan hampir beberapa abad lamanya walaupun tanpa tersadari dan berkembang hingga masa kini, tetapi belum sampai pada tataran implementasi atau praktek, sehingga sulit mengukur parameter atau indikator prilaku manusia yang sangat dinamis. Ilmu eko-psikologi termasuk ilmu yang baru berkembang, tetapi secara aplikatif sudah terimplementasikan dalam kehidupan masyarakat lampau hingga masyarakat kini. Sampai kini belum banyak metodologi yang mengkaitkan antara prilaku manusia terhadap dampak yang ditimbulkan lingkungan sekitar, tetapi hanya sebatas kajian mendasar dan belum mengena langsung akan dinamika dimensi manusia kini dan kedepan. membahas dimensi manusia sangatlah kompleks dan rumit, disamping itu dimensi manusia mempunyai peran dan fungsi yaitu mempengaruhi dan dipengaruhi lingkungan sekitar.

Seiring makin berkembangnya metodologi yang dipakai dalam menganalisi sebuah fenomena ekologis maupun non ekologis yang terjadi, tentunya menjadi titik balik untuk merumuskan sebuah indikator untuk mengevalusi dan merefleksinya. Kajian ekopsikologi mempunyai sebuah perjalanan yang panjang dalam perkembangannnya, apalagi dikaitkan dengan ilmu sains, seperti ekologi dan lebih empiriknya pada tatanan lingkungan. Untuk lebih jelasnya, akan dibahas secara mendalam, bagaimana perkembangan dan perubahannya sebagai ilmu yang dinamis dalam mencari dan merumuskan sebuah solusi yang berakar dari hubungan antara manusia dan alam. Sejauh ini, bagaimana bagaimana hubungan ilmu psikologi dan ilmu ekologi dalam perkembangannya? Tentunya belum banyak mengkajinya, walaupun secara tidak langsung telah terjadi sebuah integrasi keilmuan yang dinamis. Disamping itu ada sebuah istilah "Eco-Linguistik" (Einar Haugen, 1972; Mühlhäusler, 1995), dan banyak istilahistilah lain dalam mewacanakan sebuah konsep yang mampu membangun sebuah proses kehidupan yang harmoni dan seimbang, secara ekologis. Tetapi istilah tersebut, tidak akan dibahas dalam kajian ini, karena sedikitnya ruang untuk memaparkan secara komprehensif, karena terkait dengan dinamika bahasa yang digunakan sehari-hari dalam mempersepsikan alam sekitar.

Membahas atau mengkaji istilah "Integrasi",keilmuan kealaman maupun non kealaman, tentunya mempunyai konsekuensi yang panjang akan tujuan yang dicapainya, 
dalam hal ini perlu adanya pemahaman bersama dalam menciptakan sinergitas yang membangun dalam arti mampu bekerjasama secara terintegrasi. Integrasi keilmuan, sebuah konsep yang mampu menjembati atau menjadimediasi dari problematika ekologismaupun non ekologis, yang semakin rumit dan kompleks dalam mewacanakan sebuah isu yang semakin panas dan bersifat mengglobal. Hal tersebut, tentunya tidak mudah dalam membedah akan hubungan tersebut, tetapi ini merupakan sebuah tuntutan yang harus dilakukan dalam tahap pencarian sebuah konsep atau solusi yang tepat dalam mempersepsikan fenomena alam yang terjadi kini dan kedepan. Olehkarenaitu, sepatutnya kajian denganberagampendekatan,menjadi wacana-implementatif yang harusdilakukan, secara konsisten dan berkelanjutan, dalammembangunharmonisasitatanankehidupan yang komprehensifdanintegratif, baiksecaraekologismaupun non ekologis.

\section{PEMBAHASAN}

Mengacupada Kurt Jax (2006), konsepekologimemiliki unit-unit dalamkajiannya, walaupunbegitukajiannyamemilikiperanpentingdalammenilaisebuahtatananalamsecaraek ologis, yang tentunyadilihatdariaspekkawasan yang diamati.Di sampingitu, kajiankajiannyaseringmengangkatisu-isumengenai kelestarian alam (konservasi), yang sudah menghiasi wacana disetiap forum-forum maupun media diberbagai belahan dunia. Hal tersebut, sepatutnya menghasilkan sebuah Output yang baik, ketika diimplementasikan dalam arti bagaimana manusia berinteraksi atau berhubungan dengan alam dengan baik.Olehkarenaitu, dimensi psikis manusia terhadap siklus alam, tentunya menjadi bahan refleksi maupun evaluasi yang dalam, disamping bagian dari kebijakan yang harus dikuatkan dengan sanksi-sanksi sosialyang dapat membuat sadar. Bentuk aplikasi ataupun implementasi dari rumusan konsep teoritis sudah banyak dilakukan, tentunya hasilnya sangat bagus dan dinamis, tetapi yang menjadi kendala adalah bagaimana menerapkan secara riil/nyata dikehidupan masyarakat yang beragam, baik dari sisi kepentingan, sosial, budaya, ekonomi, agama, dan politik didalamnya. Di sampingitu, secara umum aspekagama menjadi wacana atau isu yang menarik, terkait bagaimana dimensi agama mulai mempertanyakan kembali sains dalam peran dan fungsinyadalam proses pembangunan.

Dinamika hubungan agama dan sains mengalami fluaktuasi dalam perkembangannya, seakan mempunyai arah dan tujuan yang berbeda, hal tersebut, sepatutnya menjadi pertimbangan dan pemikiran yang serius. Agama tidak hanya bersifat formatif, tetapi perlu langsung dipraktekkan dalam kehidupan sehari-hari, sehingga khasanah keagamaan dapat dirasakan dan diraba akan fungsinya sebagai pedoman atau petunjuk dalam berinteraksi terhadap makhluk lainnya. Selama ini, dipahami bersama, bahwa agama bersifat parsial, dalam arti hanya bergelut dengan penafsiran tanpa adanya sebuah fleksibilitas dalam memahaminya, sehingga muncul pemahaman taqlid (Membabi buta). Hal tersebut, salah satu bagian dari terpisahnnya sebuah pemahaman yang komprehensif menjadi pemahaman yang parsial atau terkotak-kotak. Model pemahaman tersebut, menjadi awal munculnya keterpihakan atau kepentingan manusia dalam memahami dinamika alam, dimana sentuhan-sentuhannya hanya berlandaskan pada sains dan teknologi.

Secara umum bentuk implementasi dari perkembangan dinamika teori atau konsep ke ranah praktek yang lebih aplikatif sudah sepatutnya tidak hanya menjadi wacana, tetapi benar-benar dilakukan, terkait bagaimana meraih sebuah hubungan manusia dengan alam yang bernafaskan ekologismaupunagama, dalammengeloladanmemanfaatkansumberdayaalam. Di sampingitu, V. H. Dale et al (2000), polapemanfaatansumberdayalahansepatutnyaberasaskanpadaprinsip- 
prinsipekologi.Hal tersebut, jugabagiandarisolusi yang tepat dalam memecahkan permasalahan kompleksitasekologis, disampingmengarah pada aspek implementasi yang kondusif dan persuasif.Olehkarenaitu, sejauhmanaperubahandanperkembangankajianekologi, dalammenjembatanipolapolapembangunan yang diciptakandandibangunselamaini?Itulahbeberapaargumentasi yang perludikajiatauditelaahdariberbagaiperspektif.

\section{KajianEkologi Dalam Perkembangannya}

Elaborasi dan kolaborasi dalam berbagai bidang keilmuan sangat perlu dilakukan dan diintensifkan dalam merumuskan sebuah keputusan yang mampu memberi kontribusi dan solusi yang akurat, walaupun tidak sampai 100\%. Hal tersebut, terkait dengan permasalahannya yang kompleks dan dinamis, sehingga perlu adanya sebuah penelitian yang panjang dan berkelanjutan. Sejauh ini, perubahan dan perkembangan ilmu mengalami pertumbuhan dan perkembangan, terutama dalam metodologinya, tentunya ini menjadi kabar yang menarik untuk diikuti dan dipahami akan dinamikanya. Diketahui bersama, bahwa perkembangan ilmu, akan selalu diikuti dengan perubahan-perubahan baik secara sosial, budaya, ekonomi, teknologi terapan danbahkan tatanan ekologilingkungan kini dan kedepan. Itulah yang menjadi masalah pokok, timbulnya kompleksitas permasalahan ekologismaupun non ekologis, yang makin rumit dicari dan dipahami secara komprehensif dan terintegrasi. Dinamika perkembangan keilmuan yang terus melaju, sangat terkait dengan perubahan paradigma yang dibangun manusia kini, ini mengindikasikan bahwa paradigma menjadi parameter perkembangan dari metodologi, terutama dalam kajian ekologi dalam memahami ritme alam, dengan pendekatanpendekatan yang terus dikembangkan (Gerald J. Niemi and Michael E. Mcdonald, 2004).

Sebagaimana yang dipahami bersama, bahwa kajian dimensi manusia tidak hanya seputar wacana saja, tetapi sudah mengarah pada perubahan sikap yang aplikatif, tetapi yang menjadi titik lemah dalam bentuknya adalah sulitnya mengukur prilaku manusia dalam berinteraksi dengan alam sekitar. Kajian ekologi mencoba untuk menulusuri prilaku manusia secara empirik, dimana mengarah pada sifat-sifat dari dampak yang ditimbulkan atas hasil interaksi antara manusia dan alam sekitar. Alam sekitar ini, mencakup keseluruhan sistem atau daur energi maupun non energi yang berjalan secara natural dan unnatural. Tentunya ini menjadi bagian yang belum tersentuh oleh perkembangan sains yang hanya menitik beratkan pada teknik pengelolaan dan penggunaan yang optimal dengan teknologi saja, sehingga perlu adanya kajian kolaborasi dari berbagai bidang keilmuan, terutama kajian ekologi dan kajian psikologi. Dua keilmuan tersebut, penulis mencoba untuk Re-kolaborasi untuk mengevaluasi fenomena yang sangat terkait dengan ketimpangan atau ketidakseimbangan dinamika alam maupun manusia didalam kehidupannya.

Konsekuensi dari elaborasi dan kolaborasi keilmuan tersebut, telah membawa khasanah baru untuk lebih memahami kompleksitas permasalahan ekologis maupun non ekologis yang makin carut marut akan kepentingan dan ketergantungan manusia terhadap sumber daya alam. Selama ini, belum banyak kalangan ilmuwan sains mengeksplore lebih dalam akar dari permasalahan yang timbul, disamping itu peran agama didalamnya tidak banyak dijadikan referensi utama, sehingga hubungan Manusia, Alam, dan Tuhan seakan memudar. Sepatutnya kajian ekologi menjadi model dari perkembangan kajian psikologi yang mengarah pada pemahaman ke-Besaran Tuhan sebagai pencipta dan penyebabnya. Kajian ekologi dan psikologi belum banyak menyandingkan pemahaman yang komprehensif-integratif dalam menata dinamika alam yang harmonissecara keberlanjutan. 
Seiring perkembangan akan pemahaman kompleksitas permasalahan yang ada disekitar, tentunya menjadi pertimbangan penting untuk lebih mensinergiskan sebuah metodologi yang komprehensif dari beragam khasanah keilmuan. Dengan begitu, diharapkan adanya pembahasan yang kolaboratif, sehingga timbulnya sebuah keseimbangan antara sains dan agama dalam membangun sebuah keharmonisa hubungan manusia dan alam. Itulah sebuah konsep teoritik yang perlu dibangun dalam paradigma pembangunan kini dan kedepan. Disamping itu mampu menjadi media informasi yang mampu membangun sebuah kesadaran bersama dalam hidup yang penuh berkah dan saling mengisi. Kini perkembangan akan kajian fenomena alam maupun non alam (Sosial), sudah banyak dilakukan diberbagai kalangan pemikir baik dalam forum nasional, bahkan sampai ketingkat internasional(Soetomo, 1995).

Kajian ekologi, dikaitkan dengan kerusakan atau ketidakseimbangan lingkungan sebuah metodologi yang termasuk dalam khasanah ilmu lama, yang terus berubah dan berkembang, yang tentunya metode kerjanya untuk mengetahui atau mencari parameter dari dimensi ekologis maupun non ekologis, dilihat dari aspek kecenderungan atau motivasi manusia dalam berinteraksi dengan lingkungan sekitar. Selama ini, terasa dan terlihat secara tidak langsung hubungan manusia dengan alam menjadi dilema yang kini belum menemukan sebuah solusi yang sesuai dan seimbang. Dinamika tersebut, telah mencapai puncaknya, maka terjadilah sebuah bencana yang intensitas dan durasinya semakin meningkat. Sejauh mana, peran yang dimainkan oleh ilmu ekologi untuk berkontribusi memperbaiki atau merestorasi tatanan ekologi-lingkungan kini dan kedepan? tentunya ini menjadi tantangan dalam mencari parameter yang sesuai dengan fenomena yang ada.

Kolaborasi sebuah keilmuan, tentunya menjadi bagian dari dinamika dalam mencari sebuah konsep (Teoritis) yang mampu mengubah paradigma pembangunan, kemudian mengubah arah pada tataran praktek yang diharapkan. Kajian "Eco" dan "Lingkungan" merupakan perkembangan konsep yang dibangun atas akumulasi dari permasalahan lingkungan yang makin masif dan destruktif, yang tentunya ini menjadi kajian menarik yang perlu dipahami secara komprehensif. Kajian tersebut, tentunya sangat terkait dengan ilmu alam, seperti "Ekologi" yang tentunya sudah mengarah pada kajian pada prilaku manusia, lebih mudahnya disebut "Ekologi Manusia". Adapun pada bidang ilmu lainnya, yang terkait dengan kajian dalam makalah ini adalah "Psikologi" artinya prilaku manusia yang diamati, diukur, dan dinilai dari aspek motivasi yang akhirnya terwujud pada ranah kepentingan atau tujuan hidup selama ini. Inilah sebuah kajian yang menarik untuk lebih digali dan didalami peran dan fungsi manusia selama berproses hidup, yang mungkin belum banyak dibahas secara mendalam dan komprehensif serta terintegrasi.

Di lain pihak, ilmu ekologi juga kajian ilmu yang terus mengalami perubahan dalam perannya untuk mencerna segala persoalan yang terus berkembang, terutama terkait dengan prilaku mahkluk hidup, tidak hanya manusia, tetapi juga hewan, tumbuhan, dan bahkan pada level mikroorganisme. Tentunya ini menunjukkan sebuah tuntutan untuk terus mengembangkan metodologi yang sesuai dengan fenomena yang muncul, disamping mampu menjelaskan atau mendeskripsikan secara detail dan komprehensif. Kajian tersebut, merupakan sebuah sistem yang saling terkait, sehingga apapun hasil analisanya, sepatutnya tidak boleh dilihat dari satu aspek. Inilah salah satu kelemahan yang sering dialami peneliti monodisiplin, sehingga tidak membuahkan sebuah solusi yang tepat dan akurat.

Ekologi bagian dari dinamika keilmuan yang kompleks dan berkesinambungan, disamping itu bagian dari kumpulan-kumpulan kajian ilmu lainnya. Ekologi sebuah kajian ilmu yang mampu menjaring dan menghubungkan ilmu lainnya, tetapi ini 
tergantung dari kemampuan untuk menangkap dan menganalisanya. Apalagi disandingkan dengan Psikologi yang bertautan dengan dimensi manusia secara keseluruhan. Diketahui bersama, bahwa kajian ekologi memiliki dimensi yang berkaitan dengan alam dan manusia, sedangkan psikologi adalah manusia, sehingga kedua keilmuan tersebut, sebuah kajian keilmuan yang saling kait-mengkait atau pengaruhmempengaruhi yang selama ini belum banyak dikaji secara holistik. Olehkarenaitu, tentunya ini, menjadi langkah awal untuk lebih memahami akar permasalahan yang kini belum tersentuh dan terukur secara valid atau signifikans. Sepanjang perjalanan dalam perkembangan kedua ilmu tersebut, kini bukan lagi sekedar hanya sebuah wacana atau isu belaka, tetapi sudah masuk ke ranah aplikasi atau implementasi. Sepatutnya kedua kajian dari keilmuan tersebut, mampu menjembati atau mediator dalam menginspirasi sebuah terobosan yang tepat dalam berkontribusi lebih banyak khasanah keilmuan yang lebih aplikatif, adaptif, dan persuasif. Seiring dengan perkembangan akan metodologi, tentunya menjadi titik awal untuk mengamati dinamika khasanah keilmuan yang terus melaju dengan paradigma yang dibawanya.

Paradigma pembangunan, tentunya menjadi perhatian bersama dalam melihat dan mengkaji secara komprehensif, terkait bagaimana pola pembangunan sekarang seakan telah menjauh dari keseimbangan alam. Selama ini, ketidakseimbangan lingkungan atau alam, kalau dibedah dan dianalisis akan memberikan sebuah khasanah atau menciptakan warna yang dinamis, terkait dengan perlu tidaknya sebuah metodologi yang mampu menjembati dikotomi keilmuan yang terus berjalan dalam perjalanannya. Titik temu, tentunya sulit dilakukan, ketika perdebatan mengenai fenomena yang terjadi tidak saling mengisi, tetapi saling menyalahkan. Oleh karena itu sinergitas dalam membangun paradigma yang harmoni sangat dibutuhkan dalam masa kini dan kedepan. Ilmu ekologi, kini mengalami sebuah kemajuan pesat, seiring dengan perkembangan permasalahan yang muncul dengan dampak yang dibawanya, disamping itu kajiannya sudah mengarah pada berbagai perspektif secara komprehensif.

\section{Dinamika Kajian Ekologi, Dalam Membangun harmonisasi atauKeseimbangan Ekologismaupun Non Ekologis}

Pemahaman lain yang dapat ditarik dari kedua keilmuan tersebut, ilmu ekologi bagian dari keilmuan "sains" seperti yang telah diuraikan pada alinea sebelumnya, sedangkan ilmu psikologi bagian dari representasi keilmuan "agama" yang tercermin dari keyakinan atau keimanan. Selama ini, banyak uraian atau penjelasan yang hanya mendeskripsikan sepotong-potong fenomena yang terjadi, terutama masalah ketidakseimbangan alam atau lingkungan sebagai akibat dari paradigma pembangunan yang berkembang dan berubah-ubah. Membangun dan menciptakan sebuah bangunan yang harmonis dan penuh warna dalam interaksi antara manusia dan alam, merupakan pekerjaan yang sulit dijangkau, sehingga perlu diadakannya sinergitas antar keilmuan secara komprehensif dan kontuinitas. Menjakau dan menjelah dari akar tujuan membangun sebuah integrasi keilmuan, tentunya membawa sebuah pemahaman baru dalam menemukenali permasalahan yang terjadi. Dipahami bersama, bahwa selama ini kajian-kajian yang berkaitan dengan agama dan sains selalu bertolak belakang, dalam arti hanya melihat dari satu aspek, sehingga tidak mengherankan, jikalau hasil analisanya tidak tajam atau tidak tepat sasaran.

Membangun sebuah hubungan yang harmonis dan seimbang dalam masa-masa kini, tentunya bukan pekerjaan yang mudah. Ketidakmudahan tersebut, tercermin dari makin carut marutnya bangunan yang diciptakan manusia dalam peradabannya dalam 
mencapai kehidupan yang layak. Dimensi ekonomis, tentunya menjadi faktor penting untuk melihat fenomena secara komprehensif dalam mengukur dampak yang ditimbulkannya. Oleh karena itu manusia terbelenggu dengan kepentingan yang sesaat atau berjangka pendek. Eksploitasi secara besar-besaran seakan telah menjadi paradigma pembangunan kini, sehingga tanpa tersadari telah membawa sebuah ketidakharmonisan hubungan manusia dengan alam. Inilah penting untuk ditelusuri hubungan manusia dan alam dilihat dari perspektif ilmu ekologi dan ilmu psikologi. Secara runtut dan sistematis dimensi manusia harus dikaji secara komprehensif dan terintegrasi, dalam mencapai sebuah konsep yang mampu menciptakan bangunan hidup yang seimbang yang tercermin dari hubungan manusia dan alam secara harmonis.

\section{Dimensi KajianEkologi sebagai Sains dan Agama sebagai Keyakinan}

Dimensi keyakinan yang membentuk arah prilaku atau pedomanan tata cara berhubungan dengan alam sekitar merupakan bagian dari rasa keimanan/kepercayaan seseorang, yang tentunya mempunyai agama (Islam maupun non Islam sekalipun). Segala bentuk intervensi manusia terhadap alam, tentunya menimbulkan konsekuensi yang mudah atau sulit terprediksi secara akurat dan detail. Instrumen yang digunakan untuk mengukur atau menilai sebuah fenomena alam, tentulah tidak mudah dilakukan, hanya saja bisa dikembangkan dengan pendekatan-pendekatan yang sesuai dengan permasalahan yang muncul atau kondisi pada umumnya. Sains dengan metodologinya mengalami perkembangan yang sangat pesat dengan terobosan-terobosan barunya, sedangkan agama masih berkutat pada hal-hal yang sifatnya normatif dan monoton, sehingga sulit dilakukan langkah dalam mengelaborasi atau kolaborasi, jikalau masih saling menyalahkan dan membenarkan secara buta. Wacana mengenai adanya "Integrasi" keilmuan menimbulkan sebuah optimisme kalangan pemikir, untuk bisa bangun dari keterpurukan kemajuan sebuah metodologi yang terus berkembang, terutama di negara maju atau eropa, tentunya ini menjadi pekerjaan bersama bagi masyarakat yang beragama untuk lebih pro aktif dan mampu mengikuti dan mengasimilasinya dengan optimal. Sejauh ini, apa yang menyebabkan masih terjadinya dikotomi keilmuan yang berlanjut? Dikotomi, sepintas telah dipaparkan pada alinea sebelumnya, tetapi yang menjadi dasar dari probelmatika tersebut, terkait dengan ketertinggalan dalam memahami dan mengikuti perubahan zaman yang didasari atau ditumpangi sains.

Ekologi dan Agama sepatutnya menjadi dua khasanah keilmuan yang dinamis dalam mendeskripsikan secara subjektif dan gamblang sebuah fenomena alam maupun non alam secara tuntas, juga perlu adanya kreativitas dan inovatifitas dalam menciptakan sebuah metodologi yang sesuai dengan keperluannya. Kedua keilmuan tersebut, seakan menjadi bagian dari representatif dari paradigma yang dibangun dan dikembangkan sesuai dengan kebutuhan zaman, tetapi bila dikaitkan dengan aspek agama sebaliknya. Dengan begitu objek yang dianalisa dalam kajian keilmuan tersebut, mengarah pada hubungan manusia dan alam dari perspektif ekologi dan psikologi untuk menemukenali titik ukur yang dapat dijadikan barometer dampak dari hubungan tersebut. Sains dan keyakinan dua paradigma yang selalu mengalami benturan dalam implementasinya, sehingga sulit mengelaborasi secara komprehensif dan terintegrasi. Perlu adanya langkahlangkah pasti dalam menyusun metodologi yang kuat untuk menemukan sebuah konsep yang jitu.

\section{Dimensi Manusia Dalam Perspektif Ekologi}

Sungguh luar biasanya fenomena yang terjadi kini, terkait dengan ketergantungan manusia terhadap alam dalam kebutuhannya untuk mencapai sebuah keseimbangan baik secara jasmani dalam arti biologis maupun non jasmani (Non biologis). Banyak kajian- 
kajian yang membedah dimensi manusia dalam berinteraksi dengan alam, baik dalam bidang sosial, budaya, ekonomi, politik, dan tidak kalah pentingnya adalah filsafat manusia yaitu mencoba mengevaluasi kembali peran manusia dalam berhubungan dengan alam selama ini. Manusia sebagai mahkluk yang sangat dinamis, rumit, lengkap, dan mempunyai potensi untuk memilih serta potensi yang belum tergali secara detail dan komprehensif, sehingga sulit secara langsung menjustifikasi tujuan dari hidup manusia dipermukaan bumi ini. Membahas akan kepentingan dan tujuan yang ingin dicapai oleh manusia sangatlah sulit untuk memprediksinya, karena dipengaruhi kondisi dan situasi lingkungan yang dinamis. Tentunya ini membutuhkan banyak kacamata untuk menafsirkan dan menggali potensi yang dapat menyebabkan dampak yang ditimbulkan atas hasil kegiatan manusia selama ini. Manusia dengan segala potensi yang dimiliki, secara umum mengalami perubahan dan perkembangan yang pesat, indikator yang dapat dilihat adalah banyaknya kemajuan yang telah diraih, terutama dalam bidang sains dan teknologi yang semakin modern dari berbagai penggunaannya. Konsekuensi dari kemajuan tersebut, tentunya menjadi kajian yang perlu dibedah secara komprehensif dan terintegrasi, karena terkait dengan keberlanjutan hidup manusia yang manusiawi.

Sejauh ini, dimensi manusia telah melampau batas kemampuan alam untuk memenuhinya, sehingga perlu adanya sebuah refleksi dan evaluasi yang mendalam memahami hubungan yang sejatinya. Manusia dengan segala kemampuannya, telah membangun sebuah era yang semakin modern dengan terciptanya produk teknologi yang makin berdaya guna, seperti yang telah diuraikan pada alinea sebelumnya. Manusia bukanlah mahkluk hidup yang statis dalam arti berdiam diri ditempat, tetapi sangat dinamis dalam berbagai perspektif. Membedah dan mengekplore dimensi manusia secara obsolut, tidak mudah dilakukan atau sulit dilakukan, karena sifatnya yang sangat mobil dan berubah-ubah setiap saat. Perubahan tersebut, tergantung dari situasi dan kondisi lingkungan sekitar, dimana lingkungan mempunyai makna yang luas dari unsur-unsur dari lingkungan meliputi lingkungan biotik dan abiotik, lingkungan sosial, budaya, dan politik, lingkungan ekonomi. Dengan begitu, sangat kompleks dan rumit, jikalau memahami manusia dari satu perspektif saja. Ini menunjukkan bahwa, manusia sangat berpengaruh dan dipengaruhi oleh faktor internal dan eksternal dalam eksistensi proses kehidupannya. Dalam hal ini, dimensi manusia terkait dengan kajian ini, hanya memfokuskan dinamika manusia dari perspektif ekologi dan psikologi dalam perkembangannya.

\section{Dimensi “Eco”, DalamTatananEkologi-Lingkungan}

Mengkaji seputar permasalahan yang berkaitan dengan lingkungan, tentunya menjadi wacana yang terus berkembang ditengah-tengah masyarakat yang begitu beragam akan kepentingan dalam kehidupannya sehari-hari. Manusia tidak henti-hentinya berinteraksi dengan lingkungan sekitar, terutama dalam pengelolaan dan pemanfaatan sumber daya alam sekitar, sehingga lambat laun hasil atau dampak dari interaksi tersebut, akan menjadi pokok masalah yang kini terus berkembang dan berubah. Perkembangan pokok permasalahan tersebut, seiring dengan pencapaian tingkat perekonomian yang menjadi titik ukur sebuah masyarakat yang sejahtera dan maju. Hal tersebut, terkait dengan aspek lingkungan yang menjadi isu menarik untuk dikaji secara komprehensif, terkait dengan peran, fungsi, dan dampaknya terhadap kehidupan mahkluk hidup, disamping sebagai bagian dari kebutuhan mutlak dan berkelanjutan. Kini banyak para pemikir diberbagai bidang keilmuan mengkawinkan beragam kajian lintas disiplin ilmu, yang pada umumnya mencapai sebuah konsep baru dalam memaknahi situasi dan kondisi lingkungan yang dinamis. Istilah "Eko" bagian dari hasil percampuran keilmuan yang kini menjadi konsep dalam model atau pola kegiatan yang bernuansa menjaga atau 
melestarikan lingkungan. Kajian "Eko" menjadi pembahasan yang menarik, ketika disandingkan dengan kerusakan lingkungan sebagai akibat dari peradaban modern yaitu pola pembangunan yang hanya menitik beratkan pada ranah ekspoitasi tanpa adanya perhitungan, terkait dengan keberlanjutan atau kelestariannya.

Konsep "Eko" sebuah paradigma baru yang merupakan akumulasi dari respon dari berbagai fenomena lingkungan yang terus dinamis, disamping itu sudah banyak istilah tersebut, diaplikasikan diberbagai bidang, baik pada ranah konsep teoris maupun empiris. Konsep Eko sudah menjadi trenitas peradaban dalam pola pembangunan, yang kini sering digunakan sebagai labelitas dalam setiap produk yang dicipta. Membahas "Eko" terkait dengan aspek psikologi, tentunya sangat terkait dengan dimensi manusia, terutama dalam sifat-sifat yang mendasari manusia dalam berinteraksi dengan lingkungan sekitar, yang selama ini belum banyak disentuh oleh para pakar atau pemikir. Munculnya sebuah konsep "Eco" tersebut, tentunya sebuah gebrakan model atau pola pembangunan yang mampu mencapai sebuah konsep keseimbangan dalam siklusnya. "Eko" dan "Keseimbangan" merupakan perpaduan konsep yang tepat dalam merespon perubahan lingkungan dan dampaknya, sehingga dimensi manusia yang perlu dikaji terkait dengan interaksinya selama dalam kehidupannya sehari-hari.

\section{Eco-Minded: Paradigma Model Pembangunan dalam Restorasi Alam yang Berkelanjutan}

Kajian mengenai model atau pola pembangunan yang dinamis sering mengalami perubahan dan perkembangan, seiring dengan paradigma yang diusungnya. Akhir-akhir ini model pembangunan yang berbasis "Eco" menjadi wacana disetiap derap dinamika model pembangunan yang menyatu dengan alam. Istilah "Eco" seakan menjadi bomming dalam era globalisasi ini, disamping sebagai iklanisasi disetiap produk, baik dibidang industri maupun non industri. Disamping itu istilah "Eco", bagian dari kajian "Ekologi" yang mengalami perkembangan didalam kajian ilmu yang lebih aplikatif, kuratif, dan preventif didalam merespon permasalahan lingkungan yang makin destruktif. Istilah "Eco" juga mengalam perkembangan dalam pemahamannya, dimana sering terdengar istilah "Eko-Pesantren", "Green Campus", "Green Education", "Green Economy", dan lain sebagainya. Wacana tersebut, tentunya menjadi kajian yang menarik, terkait adanya sebuah kebijakan yang mengarah pada perbaikan dan peningkatan mutu lingkungan yang berkualitas, seiring dengan pemanfaatannya, sehingga terbangun sebuah pola atau model pembangunan yang berkelanjutan. Dinamika perubahan model pembanguan tersebut, merupakan akumulasi dari buah pemikiran empiris mengenai eksistensi kehidupan makhluk yang ada dipermukaan planet satu-satunya ini, walaupun ada wacana planet lain yang menjadi habitat baru dimasa depan. Variasi dalam implementasi "Eco" dalam model pembangunan kini, seakan menjadi terobosan atau solusi baru yang tepat dalam menanggapi sebuah tuntutan bersama didalam memperbaiki lingkungan, tetapi apakah tercapai sebuah paradigma pembangunan yang humanis, harmonis, dan keserasian, jikalau dimensi manusia sendiri belum tersentuh atau terintervensi dengan "Eco"? inilah sebuah permasalahan yang dilematis yang belum terjawab secara komprehensifdanintegratif.

Merespon akan pemikiran yang berkembang dalam mengimplementasikan sebuah paradigma baru, tentunya dimensi manusia sebagai agen utama dalam perubahan tersebut, terlibat langsung dalam dinamikanya, sehingga perlu adanya sebuah elaborasi dalam memahami dinamika manusia dalam mempersepsikan akan lingkungan sekitarnya. Banyak kalangan pecinta lingkungan, bahkan penggiat restorasi lingkunga, tetapi sebagian masih melakukan kegiatan yang dikatakan dapat berkontribusi dalam perubahan lingkungan. Memunculkan sebuah perubahan dalam dimensi manusia secara keseluruhan 
dalam menapaki sebuah kehidupan yang seirama dengan alam sangat tidak mudah, disamping aspek kepentingan dan kebutuhan yang mengitarinya.

Seiring perkembangan peradaban manusia yang penuh dengan keinginan dan kepentingan didalam mencapai sebuah capaian yang lebih meningkat dalam memenuhi kebutuhan hidup yang dinamis. Memahami dinamika masyarakat dalam era ini, tentunya menjadi wacana didalam penggunaan sumber daya yang ada disekitarnya, dimana sebagian besar jenis sumber daya yang digunakan merupakan sumber daya yang tak terbaharuhi. Tiadanya transformasi sebuah pengelolaan dan penggunaan sumber daya alam tersebut, lambat laun dapat menjadi masalah baru dalam rentang waktu yang tidak lama, seiring dengan meningkatnya jumlah populasi manusia. Beragam hasil pemikiran dan penelitian telah dilakukan dengan hasil yang mengejutkan, hal tersebut dapat menjadi peringatan bahwa ketersediaan sumber daya alam ini terbatas, disamping itu merupakan bantahan bahwa sumber daya alam yang terkandung melimpah dan tidak pernah habis. Sepintas kalau ditarik kebelakang atau sebelum adanya sebuah transformasi sosial, budaya, ekonomi, dan politik, dalam arti masih bernuansa tipologi masyarakat konvesional atau tradisional, tentunya tidak bermasalah dengan pemanfaatan sumber daya alam sekitarnya. Tiadanya bermasalah tersebut, dapat ditelusuri akan dinamika kehidupan suku Baduy sekarang, dimana proses kehidupannya sangat sederhana dan menyatu dengan alam, berbeda dengan kehidupan masyarakat yang sudah terintervensi dengan budaya yang maju dan modern. Proses intervensi tersebut, merupakan bagian dari langkah awal dalam mengubah sebuah budaya yang

Diakui bersama, bahwa kehidupan yang sudah berkembang dan maju, tentunya mempunyai kekurangan dan kelebihan didalam prosesnya, hal tersebut sepatutnya menjadi kajian yang berkelanjutan untuk memahaminya dengan komprehensif dan terintegrasi. Secara tidak langsung perubahan tersebut, akan mengarah pada pola atau model pembangunan yang lebih modern. Modernitas menjadi paradigma baru pada masyarakat yang sudah berbudaya tinggi, disamping telah mampu menciptakan dan mempergunakannya dalam mempermudah aspek prosesi kehidupan masyarakat tersebut. Mengkaji dinamika perubahan tersebut, sangatlah penting untuk mengetahui secara kompleks.

\section{Eco-Development: Wujud dari AkumulasiDampakEkologisdan Non Ekologis}

Kebersamaan dalam memahami dan mengaplikasikan sebuah paradigma pembangunan yang sinergis dan seimbang, tentunya menjadi pekerjaan yang tidak hanya dititik beratkan pada salah satu bidang tertentu, begitu juga melibatkan peran masyarakat. Kecerdasan ekologis (Hultkkrantz, dalam Sternberg, 2004; Utina, 2012), buah dari peran masyarakat pembelajar yang selalu atau mampu mengikuti paradigma pembangunan, yang kemudian mampu menganalisanya secara komprehensif. Salah satu contoh dalam perencanaan pembangunan Mall atau sebagainya, karena mempunyai dampak langsung terhadap kondisi lingkungan sekitar.

Mewujudkan sebuah model pembangunan berbasis "Eco" menjadi pencapaian yang diharapkan mampu mengatasi permasalahan terkait aspek lingkungan fisik, tetapi juga dapat menciptakan keharmonisan antar lingkungan dan manusia serta sebaliknya. Keseimbangan baik secara ekologis, yang mencakup aspek hidrologis, tata ruang, dan tata iklim serta sebagainya, disamping aspek-aspek yang sifatnya non ekologis, seperti sosial, budaya, ekonomi, dan politik yang mendukung proses pembangunan yang berkelanjutan. Kini pemahaman akan pembangunan berkelanjutan dalam arti bukan sekedar mampu menyediakan generasi selanjutnya, tetapi juga mampu menyeimbangkan kebutuhan baik secara jasmani maupun rohani. Pencapaian sebuah paradigma model pembangunan semacam itu, bila dikaji dengan realitas sekarang terasa sulit untuk diimplementasikan, 
terkait dengan kepentingan dan kebutuhan manusia yang bersifat materialistik dan hedonistik. Secara perlahan aplikatif model pembangunan yang berbasis "Eco" diharapkan mampu mengubah gaya hidup masyarakat kini secara mendasar.

Model pembangunan yang memperhatikan unsur-unsur lingkungan secara komprehensif, tentunya akan membawa konsekuensi yang mengarah pada pembangunan yang memanusia atau memuliakan, jikalau pola pembangunan tidak hanya mengeksploitasi, tetapi eksploirasi. Wujud dari model pembangunan tersebut, tercermin dari bagaimana masyarakat dalam memanfaatkan sumber daya alam untuk proses kehidupan tidak merusak, tetapi menjaga secara lestari atau menggunakannya secara bijak. Hal tersebut, tidak hanya bagi masyarakat, tetapi juga birokrasi dalam membuat kebijakan yang terkait dengan pola atau model pembangunan yang dibangun, sehingga perlu adanya kerjasama antar komponen. Mewujudkannya memang terasa tidak mudah, seiring dengan dinamika kehidupan lokal maupun global dalam mengikuti perkembangan zaman yang kini mengarah pada tuntutan yang makin meningkat, sebagai respon atau dapat pengangkuan dapat mengikuti perubahan tersebut. Mengiringi sekedar mendapat pengangkuan atau tidak ingin tertinggal dengan Negara lain, tentunya menjadi masalah sendiri, berkaitan dengan sosial budaya yang berbeda-beda.

Durasi dan intensitas masyarakat dalam pergulatannya dengan dinamika pembangunan yang tidak bermakna, telah membawa sebuah perubahan yang mendasar, terkait dengan kajian-kajian lingkungan yang tidak hanya mengkaji dari aspek fisik, tetapi non fisik, seperti dikaitkan dengan budaya atau dimensi manusia dalam berinteraksi dengan lingkungan sekitar. Kini perkembangan dalam pemikiran, mengenai merespon dan mengimplementasikan perubahan lingkungan, tidak hanya menciptakan teknologi atau mengembangkan metodologi belakan, tetapi akan/sudah mengarah pada restorasi diri (Baca: Kristiyanto), yang terimplementasikan pada perubahan pemikiran (Minds). Doktrinasi mengenai restorasi diri mengenai kerusakan lingkungan, kini menjadi tuntutan yang tidak bisa ditunda dalam derap pola pembangunan kini dan kedepan.

\section{KESIMPULAN}

Paradigma pembangunan yang diusung pada era ini, secara tidak langsung telah mengarah pada sifat yang destruktif dengan sifat yang makin masif, baik intensitasnya maupun durasinya. Tentunya ini, membawa sebuah malapetaka besar bagi kelangsungan mahkluk hidup, baik secara ekologismaupun non ekologis. Parameter yang dapat menjadi tolak ukur dari masalah tersebut, terilustrasi adanya ketidakseimbangan dalam memanfaatkan sumber daya yang ada, ekspolitasi secara besar-besaran seakan menjadi agenda dari kebijakan, baik dari pemerintah pusat maupun daerah. Disamping itu, fenomena tersebut, seiring dengan semakin berkembangnya sains dan teknologi yang tercipta selama ini, tidak terpungkiri membawa sebuah dampak yang luar biasa dalam kehidupan manusia dan berbagai lini.

Sebuah bencana yang besar, bilamana tanpa adanya sebuah pencegahan yang pasti, yang tentunya membutuhkan sebuah solusi yang tepat. Banyak kajian-kajian yang mencoba memahaminya, tetapi sampai kini masih sebatas permukaan, sehingga masalah terus ada, sebelum masalah pokoknya belum tuntas.Adapundipihaklain, pembangunan yang berbasis "Eco" kini mulai berkembang ditengah-tengah masyarakat modern, dimana konsep tersebut, diharapkan mampu mencegah dan minimalisir dampak dari proses pembangunan. Sampai kini, belum ada instrumen yang sesuai dan valid $100 \%$ digunakan mengukur dampak dari pembangunan. Dilain pihak perkembangan ilmu ekologi dan psikologi mengalami kemajuan yang sangat pesat, dimana sudah mengarah pada kajian-kajin yang elaboratif dan komprehensif. Sepatutnya ini menjadi harapan 
untuk bisa membedah permasalahan pembangunan secara tuntas atau berdasarkan penyebab akar permasalahannya.

Harapan kedepan, terkait dengan model atau pola pembangunan adalah mewujudkan sebuah paradigma pembangunan yang harmonis dalam arti tiadanya masalah besar dan merugikan baik secara materi maupun non materi. Proses kolaborasi dan elaborasi dari berbagai disiplin keilmuan menjadi khasanah dinamika dalam perkembangan ilmu dari berbagai perspektif. Sepatutnya proses "Integrasi Keilmuan" menjadi agenda yang perlu dikuatkan kembali, karena akan dapat membuahkan sebuah konseptual pada tataran teori ke empirik. Manusia dan alam menjadi bagian siklus hidup yang saling terkait dan tak terpisahkan, sehingga merajut hubungan yang harmonis akan sangat saling menguntungkan (Simboisis Mutualisme), yang selama ini terjadi kerengganan.

\section{DAFTAR PUSTAKA}

Abidin, Z. Filsafat Manusia: Memahami Manusia Melalui Filsafat. Penerbit PT Remaja Rosdakarya, Bandung. 2003

Alikodra, H. S. Teknik Pengelolaan Satwa Liar: Dalam Rangka Mempertahankan Keanekaragaman Hayati Indonesia. IPB Press, Bogor. 2010

Al-Goyani, U. Y. GreenSpeak, Menuju Keseimbangan Lingkungan. Opini, 2010 (http://sosbud.kompasiana.com/2010/01/08/\%E2\%80\%98greenspeak\%E2\%80\% 99-menuju-keseimbangan-lingkungan-50248.html (Diunduh 17/6-2013)

Baqir, et al. Integrasi Ilmu dan Agama: Interpretasi dan Aksi. PT Mizan Pustaka, Bandung. 2005

Coleman, C, David. Collaboration and Conflict in International Ecological Research.Frontiers in Ecology and the Environment, Vol. 9, No. 7 (September, 2011), 414-415.

Dale, H. V et al. Ecological Principles and Guidelines for Managing the Use of Land.Ecological Applications, Vol. 10, No. 3 (Jun., 2000), 639-670.

Fromm, E. Manusia Menjadi Tuhan: Pergumulan Tuhan Sejarah dan Tuhan Alam. Penerbit JALASUTRA, Yogyakarta. 2011

Hodges, E. Karen. Defining the Problem: Terminology and Progress in Ecology.Frontiers in Ecology and the Environment, Vol. 6, No. 1 (Feb., 2008), 35-42.

$\begin{array}{lllll}\text { Izzad, R. Agama dan } & \text { Sains. Opini, } 2013\end{array}$ (http://filsafat.kompasiana.com/2013/01/17/agama-dan-sains-526437.html (Diunduh 17/6-2013)

I, V. Panov.Ecological Thinking, Consciousness, Responsibility.Procedia - Social and Behavioral Sciences, 86 (2013), 379 - 383.

Jax, K. Ecological Units: Definitions and Application.The Quarterly Review of Biology, Vol. 81, No. 3 (September, 2006), 237-258.

Johnson, R, Alan. Ecological Theory.Bulletin of the Ecological Society of America, Vol. 75, No. 3 (Sep., 1994), 172-173

Kaeksi, W. R. Pembangunan dan Kelestarian Sumber Daya Lingkungan Hidup. Forum Geografi No. 19 Thn X/Desember 1996

Niemi, J GeralddanMcdonald, M. E. Application of Ecological Indicators. Annual Review of Ecology, Evolution, and Systematics, Vol. 35 (2004), 89-111.

Proctor, D, James.Ecology, Complexity, and Metaphor.BioScience, Vol. 55, No. 12 (December 2005), 1065-1068.

Samuel M. Scheiner et al. An Epistemology for Ecology.Bulletin of the Ecological Society of America, Vol. 74, No. 1 (Mar., 1993), 17-21. 
Subandi. Reposisi Psikologi Islam. Disampaikan pada temu ilmiah Nasional 1 psikologi islam, Yogyakarta 24 September 2005.

http://psikologi.ugm.ac.id/uploads/resources/File/Database\%20Penelitian\%20Dos en/reposisi psikologi islami.pdf (Diunduh 17/6-2013)

Soemarwoto, O. Ekologi, Lingkungan Hidup dan Pembangunan. Penerbit Djambatan, Yogyakarta. 1994

Soetomo, G. Sains dan Problem Ketuhanan. Penerbit Kanisius, Yogyakarta. 1998

Utina, R. Kecerdasan Ekologis dalam Kearifan Lokal Masyarakat Bajo Desa Torasiaje Provinsi Gorontalo. Prosiding Konferensi dan Seminar Nasional. Pusat Lingkungan Hidup Indonesia ke-21, 13-15 September 2012, di Mataram. 